\title{
Development of the Physical Competence Scale for Elementary School Students in Japan
}

\author{
Yuta Ono and Masanori Kaji \\ Faculty of Sport Sciences, Waseda University \\ 3-4-1, Higashifushimi, Nishitokyo, Tokyo, 202-0021, Japan \\ y-ono.sps@aoni.waseda.jp \\ [Received March 12, 2019; Accepted May 29, 2020; Advance publication released online June 16, 2020]
}

\begin{abstract}
This study aims to developed a physical competence scale for elementary school students, and thereby clarify what kind of physical competences Japanese elementary school students learn in physical education as well as what characterizes physical competence for students according to grade and sex. We administered a questionnaire survey to $871 \mathrm{fifth}$ - and sixth-grade elementary school students in Japan. We found that the physical competence of elementary school students could be assessed in terms of five factors comprising a total of 19 items: a feeling of control, a feeling of approval, a feeling of omnipotence, a feeling of superiority, and a feeling of progress. Furthermore, we found that Fifth graders had significantly higher scores for a feeling of control than sixth graders did, and boys generally scored better in physical competence than girls did, except feeling of superiority. The physical competence scale developed in this study can be used to better understand elementary school students' perceptions of their own competences and experiences in physical education classes. The results of this study also indicate that improving physical competence is not always positive. For instance, the "feeling of superiority" should not be encouraged. In other words, high levels of the "feeling of superiority" could cause serious discord in classmate interaction, including the exclusion or isolation from teams of children who are unskilled at exercise. This must be examined more closely in future teaching research.
\end{abstract}

Keywords: intrinsic motivation, active learning, scale development, Course of Study

\section{Introduction}

The Course of Study that was announced by the Ministry of Education, Culture, Sports, Science and Technology (MEXT) in March 2017 prioritized "proactive, interactive and authentic learning" based on active learning (MEXT, 2018a, p. 22). The Course of Study summarizes the necessary "way of understanding and thinking" about elementary school physical education as "focusing on the value and special traits of exercise and sports, highlighting its role in creating fun and happiness and improving physical strength, and relating it to diverse ways of 'doing, seeing, supporting, and knowing' as suits each person's aptitude" (MEXT, 2018b, p. 19). The future direction for physical education in Japan is the pursuit of a learning process for discovering and solving a variety of tasks through a diverse engagement with exercise and sport that cultivates both a life-long attitude of familiarity with exercise, an attitude of appreciating the fun and joy of exercise, and engaging in independent learning activities (MEXT, 2018a, 2018b). Thus, the Course of Study emphasizes the importance of fostering learners with a lifelong desire to engage in independent physical exercise through physical education classes based on "proactive, interactive and authentic learning" (MEXT, 2018a, p. 22).

The present study focuses on learners" "intrinsic motivation," ${ }^{* 1}$ which is the motivation that is generated and regulated from within oneself while performing an activity (Deci and Ryan, 1985). Intrinsic motivation is a mental mechanism supporting a variety of social activities, such as learning and working.

How does intrinsic motivation relate to learning? According to Kage (2013), intrinsic motivation in a learning context refers to "personal goal-oriented learning motivation." That is, the learning itself is the goal that motivates; learners are eager to study because they want to know more, or they undertake a learning exercise because they want to become profi- 
cient in that activity. This perspective suggests that intrinsic motivation stems from an innate inclination to improve one's ability by challenging oneself and by exploring and learning new things. Therefore, this also holds for physical education, where promoting intrinsic motivation for physical exercise is considered an important means of sustaining learners' independent engagement (Ferrer and Weiss, 2000; Hassandra et al., 2003).

In a physical education context, intrinsic motivation is expressed as the learner's awareness of their physical competence. To begin with, a "feeling of competence" refers to one's recognition or feeling of being competent. It is considered an essential cognitive aspect of intrinsic motivation and has been identified as fulfilling an important function in improving students' learning motivation (Deci and Ryan, 1985). In subsequent research, Deci and Ryan (2002) proposed a self-determination theory consisting of three basic needs, one of which is the need for competence. The need for competence motivates people to make sustained efforts to overcome obstacles and become competent. According to Sugihara (2003), subjective physical competence can encourage the learner to engage in physical education actively, while a low level of perceived physical competence may create a sense of inadequacy. Consequently, it is thought that increasing learners' physical competence through physical education is an effective means of helping them develop the qualities and abilities necessary for a lifetime of physical exercise.

\section{Literature review}

Competence was introduced as a motivational concept by White (1959), who saw competence as a basic motivational component in learning and attainment. He initially defined competence as "effective interaction with the environment" and argued that people experience "effectance motivation," meaning that they desire to feel that they have effectively interacted with the environment. He then expanded the concept of competence, stating that competence is a "cumulative result of the whole history of transactions with the environment," which suggests that competence is an indispensable part of the motivation in learning (White, 1963).

White's model of competence was further elaborated in a series of studies by Harter (1974, 1978, 1981, 1982). Harter (1982) argued that experiences of success in daily life and support from important people contribute to improving self-appraisal, and thus developed the "Perceived Competence Scale for Children" to measure the psychological aspects of physical competence self-appraisal. This scale assumes that the structure of a child's feeling of competence consists of the following four factors: "cognitive competence," "social competence," "physical competence," and "general competence." It was a novel attempt to assess competence in students in multiple aspects of daily life, and the scale can be applied to all children.

Sakurai (1983) developed a Japanese version of the "Perceived Competence Scale for Children" and introduced it in Japan. Sakurai's (1992) "Children's Perceived Competence Scale" measures subtle individual differences in feelings of competence between elementary school students, and can be used in other ways in Japanese education research.

Harter's (1982) scale included "physical competence," which is a feeling of competence related to physical exercise. Okazawa et al. (1996) developed their "Physical Competence Scale" to measure physical competence comprehensively and clarify the developmental characteristics of the factors of physical competence for elementary school, middle school, high school, and university students. This scale evaluates three factors through twelve items: "physical competence" (confidence in one's ability to do physical exercises well); "feeling of control" (confidence in one's ability to do physical exercises well through effort and training), and "peer and teacher acceptance" (confidence that one is accepted by one's peers and teachers). The scale items were developed from other competence scales, such as those of Harter (1978), Sakurai (1983), Harter and Pike (1984), and Ito (1987).

A notable feature of the Physical Competence Scale is that it includes the new categories of "feeling of control" and "feeling of acceptance." It was difficult to find a way to induce intrinsic motivation in learners with low physical abilities or skills using only the "physical competence" indicator found in Harter (1982) and Sakurai (1983); however, Okazawa et al. (1996) included "feeling of control" and "feeling of acceptance," making it possible to measure the intrinsic motivation of diverse learners.

To address this lack further, Okazawa et al. (1996) broadly suggested the importance of raising the physical competence of learners in physical education. Since then, many practical Japanese physical educa- 
tion studies have been conducted, such as examinations of teaching plans aimed at improving physical competence. Even so, the following three main problems affecting the physical competence scale were identified.

First, do the scale items accurately reflect the characteristics of physical education teaching? In recent years, Japanese research on feelings of competence has pointed out that competence can be gained through the critical evaluation and depreciation of others' abilities (Hayamizu, Kino, Takagi, and Tan, 2004). In other words, the issue of how one recognizes others appears inseparable from the raising of self-appraisal, which means that the recognition of competence through comparing oneself to others is an important element of feelings of competence. Particularly, as physical education classes center on motor learning, the skill levels of others are readily apparent. However, the scale developed by Okazawa et al. (1996) does not consider that students' self-appraisal of physical competence is often connected to comparisons with others' abilities. In the first place, the acquisition of competence by comparing oneself with or underestimating others is not something that should be pursued in pedagogical settings. It is, therefore, necessary to develop a scale that allows us to have a close understanding of the current situation of students who are comparing themselves with and underestimating others.

Second, there is a problem with how the scale was developed. As already stated, Okazawa et al. (1996) did not conduct a pilot study to develop the scale items; instead, the items were developed based on relevant existing scales. However, as those scales were based on general learning environments, it is possible that potential factors and items characteristic of physical education were left out. In other words, there might have been factors and items relating to comparing oneself with others that were not extracted due to this data collection method. Therefore, a reexamination of the item contents for the whole scale is required because several items were used despite factor weights over .40 between the factors, as well as the fact that the validity of the scale was not verified.

Third, there is a problem concerning the subjects that the scale measures. Okazawa et al. (1996) presented their Physical Competence Scale as a common scale applicable across developmental stages, ranging from senior elementary school students to university students. However, curricula and learner development differ according to educational level, which means that whether the scale developed can be applied to each development stage is an utterly different issue from whether that scale considers the characteristics of each development stage. More precisely, we need to develop more specific scales that are suitable for each grade level and development stage to improve our understanding of the developmental progression of physical competence.

In addition to the abovementioned problems, Okazawa et al.'s (1996) Physical Competence Scale was developed over 20 years ago. As one of the primary goals of physical education studies is to apply research results to actual teaching practices, the continued use of a scale developed more than two decades ago that has not been updated is itself a significant problem.

We believe that the development of a new physical competence scale, oriented toward $21^{\text {st }}$-century physical education, is an important and urgent research task as it will contribute to the qualitative improvement of physical education teaching practices. As such, we need to develop a new physical competence scale based on the insights provided by previous studies and using revised scale development methods.

\section{Study purpose}

The purpose of this study is to develop a physical competence scale for elementary school students, and thereby clarify what kind of physical competences Japanese elementary school students learn in physical education as well as what characterizes physical competence for students according to grade and sex. Elementary school students were chosen as the focus of this study because, despite the need for such a scale at every educational level, the elementary level forms the foundation of an individual's academic and physical education.

\section{Pilot study}

\subsection{Purpose}

The purpose of the pilot study was to collect and carefully select statements on elementary school students' physical competence. 


\subsection{Survey period, participants, and procedure}

The survey was conducted in January 2018 at three public elementary schools in Tokyo, Japan. This involved a total of 309 fifth- and sixth-grade elementary school students (150 boys and 159 girls). The participants took the survey during class hours.

\subsection{Ethical considerations}

The pilot study was approved by a research ethics committee at the first author's university (Approval number: 2017-268). The questionnaire was anonymous, and it indicated that the anonymity of the participants' answers was guaranteed. We obtained consent for the survey by explicitly stating that all of the questions were voluntary and that no student was required to answer any question that they could not or did not wish to answer.

\subsection{Survey contents}

The students were asked, "At what times do you feel 'I can do this' in physical education?" and invited to provide their answer in free form.

\subsection{Results}

Regarding the free-form responses, we first excluded any answers that were unrelated to the question and then extracted statements at the clause level, thus collecting 357 statements on elementary school students' feelings of competence in physical education.

Next, we worked with a rater (an elementary school teacher) to categorize these statements based on similarities in the content. We discussed it until the research team, consisting of ..., agreed on the following five constructs of physical competence among elementary school students: "feeling of control," "feeling of approval," "feeling of omnipotence," "feeling of superiority," and "feeling of progress."

We created the scale items based on the contents of the statements that we had categorized into the abovementioned constructs. When doing this, we tried to clarify the statements, for example, by aggregating statements with similar content. We reviewed the items created through this process with the cooperation of eight current elementary school teachers and revised the statements so that they were easy for the students to understand.

Next, we verified the validity of the contents. We did this by presenting eight graduate students, specializing in physical education studies, with a list of the 20 items relating to feelings of competence and asked them to categorize the items according to the abovementioned five constructs. We determined validity according to the rate of agreement and deleted any items that had a rate of less than 60 percent.

Following this verification, we finally selected 20 items for measuring physical competence in elementary school students. We asked current elementary school teachers to revise the wording of the items so that they would be easily understood by elementary school students.

\section{Main survey}

\subsection{Purpose}

The primary objective of the present study was to develop a scale for measuring physical competence among elementary school students and assess the effectiveness of the items in the scale that were selected in the pilot study. Next, we verified the reliability and validity of the developed scale. Finally, the scale's ability to assess students' feelings of competence in physical education according to grade and sex was examined.

\subsection{Survey period, participants, and procedure}

The study was conducted in January and February 2018 and involved fifth- and sixth-grade elementary school students from nine public schools in Tokyo, Kanagawa, and Saitama. The sample population comprised 464 fifth-grade students (216 boys and 248 girls) and 407 sixth-grade students (209 boys and 198 girls), with a total of 871 students ( 425 boys and 446 girls). Of these, excluding omissions and mistakes, the responses of 866 students (425 boys and 441 girls) were deemed valid and included in the analysis. The participants took the survey in their class during their class hours. We used SPSS (version 24.0) for the statistical processing.

\subsection{Ethical considerations}

This study was approved by the research ethics committee at the first author's university (Approval 
number: 2017-268). As with the pilot study, we obtained consent for the survey by explicitly stating that all of the questions were voluntary and that no student was required to answer any question that they could not or did not want to answer. We used the same method with both grades.

\subsection{Survey content}

\subsubsection{The cover sheet}

The first questions we asked collected demographic information about the students' sex and grade level.

\subsubsection{Items for measuring physical competence among elementary school students}

We asked the respondents to choose their answers from a four-point scale, ranging from "Completely agree" (4 pts) to "Completely disagree" (1 pt) to see how well the 20 items selected in the pilot study applied to the learners' ways of thinking.

\subsubsection{Questions about actively engaging in physical education classes}

We used the responses to the survey items "I actively engage in my physical education class" (Agree: 3 pts, Neither agree nor disagree: 2 pts, Disagree: $1 \mathrm{pt}$ ) to verify the validity of the scale. This is because past studies have indicated that learners who more actively engage in learning will have greater feelings of competence (Kage, 2013; Sugihara, 2003). Bearing this in mind, there might be differences in physical competence, depending on learners' assertiveness in physical education. We thus hypothesized for the validity verification that learners who actively engage in physical education would score higher in terms of physical competence, while those who do not actively engage in physical education will score lower.

\subsubsection{The "self-esteem scale"}

When verifying the criterion-related validity of this study, we focused on the correlation between the physical competence scale and the self-esteem scale. "Self-esteem" refers to the evaluative emotion of recognizing oneself to be of value (Rosenberg, 1965; Zeigler-Hill, 2013). Studies have pointed out that it resembles a feeling of competence (Deci and Ryan, 1985; Hayamizu et al., 2004). Even so, while a feeling of competence is self-appraisal that indicates the concrete contents of "I can," self-esteem simply indicates a fundamental self-appraisal based on broad self-evaluation. From this, we can infer that the two may correlate to some extent, yet remain distinct concepts.

Therefore, our hypothesis for the criterion-related validity verification was that each factor on the physical competence scale would be positively correlated with the self-esteem scale. However, an examination by Hayamizu (2012) made it clear that there is no correlation between self-esteem and factors relating to comparing oneself with others, so we also predicted that a "feeling of superiority" does not correlate with the self-esteem scale.

We used Susaki and Anii's (2013) self-esteem scale (one factor with eight items). This scale is a revised version of Rosenberg's (1965) Self-Esteem Scale, designed to apply to Japanese elementary and middle school students and allow easier measuring. The reliability and validity of this scale have been confirmed to some extent and is as informative as the factor and ten items created by Rosenberg. We asked the respondents to choose their answers on a four-point scale ranging from "Completely agree" (4 pts) to "Completely disagree" (1 pt).

\subsection{Results}

\subsubsection{An exploratory factor analysis of the scale for measuring physical competence among elementary school students}

First, we analyzed the 20 items for measuring elementary school students' feelings of competence in physical education. To examine the items for bias, we looked at items with an average value of no more than 1.5 and those with at least 3.5 , items whose standard deviation was extremely small, and items whose normal frequency distribution had a concentration of 70 percent in a particular frequency. The results demonstrated that no such items were biased. We also calculated the correlations between the items but did not find any with a value that exceeded .70 .

Next, we conducted an exploratory factor analysis (maximum-likelihood method with promax rotation) of the remaining 20 items. We deleted one item with a factor weight of no more than .40 as well as a factor weight of at least .40 between the factors. We conducted another exploratory factor analysis (maximum-likelihood method with promax rotation) of the remaining 19 items, which resulted in the extraction of five factors (Table 1). Furthermore, as mentioned previously, the acquisition of competence by compar- 
Table 1 "Physical competence scale for elementary-school students" (Promax rotation) and factor correlation.

\begin{tabular}{|c|c|c|c|c|c|}
\hline Items & I & II & III & IV & $\mathrm{V}$ \\
\hline \multicolumn{6}{|l|}{ I Feeling of control $(\alpha=.90)$} \\
\hline $\begin{array}{l}\text { 9. I think I can do well in physical exercises that I'm not good at by making an effort. } \\
\text { (わたしは, うまくできない運動も，努力をすればできるようになると思います) }\end{array}$ & .94 & .02 & .00 & .01 & -.11 \\
\hline $\begin{array}{l}\text { 15. I think I can do well in physical exercises that I'm not good at by not giving up. } \\
\text { (わたしは, うまくできない運動も，あきらめなければできるようになると思います) }\end{array}$ & .89 & .00 & -.04 & .03 & -.01 \\
\hline $\begin{array}{l}\text { 3. I think I can do well in physical exercises that I'm not good at by practicing. } \\
\text { (わたしは, うまくできない運動も，練習をすればできるようになると思います) }\end{array}$ & .81 & -.02 & .04 & .04 & .02 \\
\hline $\begin{array}{l}\text { 20. I think I will eventually be able to do physical exercises, even if I'm not good at it now. } \\
\text { (わたしは, うまくできない運動も，最後にはできるようになると思います) }\end{array}$ & .70 & .03 & .02 & -.03 & .07 \\
\hline \multicolumn{6}{|l|}{ II Feeling of approval $(\alpha=.81)$} \\
\hline $\begin{array}{l}\text { 8. I think my friends are paying attenion to how I perform in physical exercises. } \\
\text { (わたしは, 友達から運動のパフォーマンスが注目されていると思います) }\end{array}$ & -.05 & .81 & .02 & -.04 & -.01 \\
\hline $\begin{array}{l}\text { 4. I think I can become the central figure on a team. } \\
\text { (わたしは, チームの中心的存在になれると思います) }\end{array}$ & .03 & .71 & .03 & .01 & .06 \\
\hline $\begin{array}{l}\text { 11. I think my friends and teachers are cheering me on. } \\
\text { (わたしは, 友達や先生から応援される存在だと思います) }\end{array}$ & .05 & .71 & -.06 & .08 & -.05 \\
\hline $\begin{array}{l}\text { 16. I think my friends feel comfortable asking me about physical exercises. } \\
\text { (わたしは, 友達から運動のやり方について相談されやすいと思います) }\end{array}$ & -.02 & .70 & -.01 & .01 & .00 \\
\hline \multicolumn{6}{|l|}{ III Feeling of omnipotence $(\alpha=.82)$} \\
\hline $\begin{array}{l}\text { 7. I think I can always do well in physical exercises. } \\
\text { (わたしは, いつも運動がうまくできると思います) }\end{array}$ & -.02 & .05 & .88 & -.03 & -.01 \\
\hline $\begin{array}{l}\text { 18. I don’t think there is any physical exercise that I can’t do. } \\
\text { (わたしには, できない運動はないと思います) }\end{array}$ & -.03 & -.03 & .85 & -.01 & -.12 \\
\hline $\begin{array}{l}\text { 1. I think I can do physical exercises as I intend to. } \\
\text { (わたしは, 自分のイメージ通りに運動ができると思います) }\end{array}$ & -.01 & .11 & .74 & .08 & .08 \\
\hline $\begin{array}{l}\text { 12. I often make mistakes when doing physical exercises.※ } \\
\text { (わたしは, 運動でよく失敗をします) }\end{array}$ & .12 & -.13 & .47 & .05 & .10 \\
\hline \multicolumn{6}{|l|}{ IV Feeling of superiority $(\alpha=.77)$} \\
\hline $\begin{array}{l}\text { 14. I think I'm better at physical exercises than my friends.※ } \\
\text { (わたしは, 友達よりも運動が上手にできると思います) }\end{array}$ & -.06 & -.05 & -.01 & .85 & -.01 \\
\hline $\begin{array}{l}\text { 19. I think I'm one of the persons who is good at doing physical exercises in the class. ※ } \\
\text { (わたしは, クラスの中で運動がうまくできる方だと思います) }\end{array}$ & -.06 & -.03 & -.08 & .75 & -.08 \\
\hline $\begin{array}{l}\text { 5. When I see a friend that can do exercises well, I wonder why that is.※ } \\
\text { (わたしは, 運動がうまくできない友達を見ると, なぜだろうと思います) }\end{array}$ & .01 & .05 & .01 & .65 & .03 \\
\hline $\begin{array}{l}\text { 10. Everybody thinks I’m not good at physical exercises. ※ } \\
\text { (みんなは, 運動がうまくないなあと思います) }\end{array}$ & .14 & .06 & .10 & .56 & .07 \\
\hline \multicolumn{6}{|l|}{ V Feeling of progress $(\alpha=.79)$} \\
\hline $\begin{array}{l}\text { 2. I always have high goals when doing physical exercises. } \\
\text { (わたしは, 運動に対していつも高い目標を持っています) }\end{array}$ & .02 & .02 & .01 & .04 & .83 \\
\hline $\begin{array}{l}\text { 17. I have clear goals when it comes to physical exercises. } \\
\text { (わたしは, 運動に対してはっきりとした目標を持っています) }\end{array}$ & .11 & -.01 & .02 & -.02 & .66 \\
\hline $\begin{array}{l}\text { 6. I think I want to be my best whatever exercise I'm doing. } \\
\text { (わたしは, どんな運動に対してもいつもべストをつくしたいと思います) }\end{array}$ & .29 & -.02 & -.01 & .03 & .47 \\
\hline I & - & .25 & .17 & -.14 & .54 \\
\hline II & & - & .59 & -.47 & .49 \\
\hline Factor correlation & & & - & -.42 & .55 \\
\hline (1) & & & & - & -.31 \\
\hline $\mathrm{V}$ & & & & & - \\
\hline
\end{tabular}

ing oneself with and underestimating others should not be an objective in an educational setting. Therefore, all of the items relating to comparing oneself with and underestimating others were processed as "reverse items." We then named the five factors extracted from the items' characteristics.
The first factor, the "feeling of control," contained items such as "I think I can do well in physical exercises that I'm not good at by making an effort"-in other words, the items relating to a mentality that support continuous engagement. The second factor, the "feeling of approval," contained items such as "I 
think I can become the central figure on a team"that is, items relating to the feeling of being approved by others. The third factor, the "feeling of omnipotence," contained items such as "I think I can always do well in physical exercises," which included items relating to the confidence in one's abilities. The fourth factor, the "feeling of superiority," contained items such as "I think I'm better at physical exercises than my friends" - that is, recognition of a feeling of being superior to others. Finally, the fifth factor, "feeling of progress," contained items such as "I always have high goals when doing physical exercises"- that is, items indicative of a high degree of goal-orientation in one's own engagements.

Next, we examined the internal consistency of the scale by calculating Cronbach's alpha as a coefficient of the reliability for these five factors. The results were $\alpha=.90$ for the first factor, $\alpha=.81$ for the second factor, $\alpha=.82$ for the third factor, $\alpha=.77$ for the fourth factor, and $\alpha=.79$ for the fifth factor. All of the factors yielded an alpha of at least .70, thus confirming a level of internal consistency. Furthermore, we named the scale developed in this study the "physical competence scale for elementary school students (physical competence scale)."

\subsubsection{Validity verification}

\section{(1) Verifying the validity of the constructs}

To verify the validity of the scale's constructs, we divided each factor into three groups based on whether the respondents were actively engaged in physical education (Yes, Neither, No) and conducted a one-way analysis of variance (Table 2).

The results were "feeling of control" $(F(2,866)=$ $81.88, p<.001)$, "feeling of approval" $(F(2,866)=$ $42.33, p<.001)$, "feeling of omnipotence" $(F(2,866)$ $=52.54, p<.001)$, "feeling of superiority" $(F(2,866)$ $=7.69, p<.001)$, and "feeling of progress" $(F(2,866)$ $=160.50, p<.001)$, thus demonstrating a significant main effect. A multiple comparison demonstrated that the scores were significantly higher for "Yes" than for "Neither" and "No" $(p<.001)$, except for "feeling of superiority." The score for "feeling of superiority" was significantly higher for "Neither" and "No" than for "Yes." This made it clear that learners who engaged in physical education more actively scored significantly higher on the physical competence scale. As we obtained our predicted results, we determined that our hypothesis for the verification of the validity of the constructs was supported.

\section{(2) Verifying the criterion-related validity}

To verify the scale's criterion-related validity, we conducted a correlation analysis between the physical competence scale and the self-esteem scale (Table 2). The results demonstrated a significant positive correlation (weak; $r=.24-.32$ ) between each of the factors on the physical competence scale (excluding "feeling of superiority") and the self-esteem scale. There was no correlation between "feeling of superiority" and the self-esteem scale. In this way, we again obtained the results we predicted, and we thus determined that our hypothesis for the verification of the criterionrelated validity was supported.

Table 2 Validity Verification.

2-1. Verifying the validity of the constructs: Physical competence differences based on physical education class activities

\begin{tabular}{|c|c|c|c|c|c|c|c|c|}
\hline & \multicolumn{2}{|c|}{$\begin{array}{l}(\mathrm{A}) \text { Yes } \\
(N=581)\end{array}$} & \multicolumn{2}{|c|}{$\begin{array}{l}\text { (B) Neither } \\
(N=254)\end{array}$} & \multicolumn{2}{|c|}{$\begin{array}{l}(\mathrm{C}) \text { No } \\
(N=31)\end{array}$} & \multirow{2}{*}{$F$ value } & \multirow{2}{*}{$\begin{array}{c}\text { Multiple } \\
\text { comparisons }\end{array}$} \\
\hline & $M$ & $S D$ & $M$ & $S D$ & $M$ & $S D$ & & \\
\hline Feeling of control & 3.14 & .81 & 2.43 & .82 & 2.10 & .93 & $81.88^{* * *}$ & $\mathrm{~A}>\mathrm{B}, \mathrm{C}$ \\
\hline Feeling of approval & 2.04 & .76 & 1.58 & .56 & 1.47 & .64 & $42.33^{* * *}$ & $\mathrm{~A}>\mathrm{B}, \mathrm{C}$ \\
\hline Feeling of omnipotence & 2.41 & .77 & 1.88 & .74 & 1.65 & .84 & $52.54^{* * *}$ & $A>B, C$ \\
\hline Feeling of superiority & 2.99 & .79 & 3.21 & .81 & 3.23 & .90 & $7.69^{* * *}$ & $\mathrm{~B}, \mathrm{C}>\mathrm{A}$ \\
\hline Feeling of progress & 2.90 & .78 & 1.97 & .60 & 1.78 & .76 & $160.50^{* * *}$ & $\mathrm{~A}>\mathrm{B}, \mathrm{C}$ \\
\hline
\end{tabular}

*** $p<.001$

2-2. Verifying the criterion-related validity: Correlation of the elementary school student's physical competence and self-esteem

\begin{tabular}{cccccc}
\hline & Feeling of control & Feeling of approval & Feeling of omnipotence & Feeling of superiority & Feeling of progress \\
\hline Self-esteem & $.30^{* *}$ & $.32^{* *}$ & $.32^{* *}$ & -.05 & $.24^{* *}$ \\
\hline$* * p<.01$ & & & & &
\end{tabular}




\subsubsection{Examination of fundamental statistics, grade difference, and sex difference included in the scale}

To examine the fundamental statistics, grade differences, and sex differences included in the physical competence scale, we conducted a two-way analysis of variance on grade level (fifth- and sixth-year) and sex (boys and girls; Table 3).

At first, the interaction effect was not reflected in either factor. After examining the main effect, it was found that "feeling of control" $(F(1,866)=9.14$, $p<.001)$ demonstrated a significant main effect. A multiple comparison demonstrated that the scores were significantly higher for fifth-grade students than for sixth-grade students $(p<.001)$. Furthermore, the results were "feeling of control" $(F(1,866)=6.60$, $p<.05)$, "feeling of omnipotence" $(F(1,866)=14.02$, $p<.001)$, "feeling of superiority" $(F(1,866)=23.35$, $p<.001)$, and "feeling of progress" $(F(1,866)=37.74$, $p<.001$ ), thus demonstrating a significant main effect for sex. A multiple comparison demonstrated that scores were significantly higher for boys than for girls $(p<.001)$, except for "feeling of superiority." The score for "feeling of superiority" was significantly higher for girls than for boys $(p<.001)$.

\section{Discussion}

\subsection{The factor structure of the physical compe- tence scale for elementary school students}

Here, we would first like to go through the similarities with the existing physical competence scale (the
Okazawa scale) developed by Okazawa et al. (1996).

The Okazawa scale consists of the following three factors: "physical competence," "feeling of control," and "peer and teacher acceptance." While the physical competence scale developed in the present study also includes "feeling of control," it differs from the Okazawa scale in that "feeling of approval" is similar to "peer and teacher acceptance" and "feeling of omnipotence" is similar to "physical competence."

"Feeling of control" indicates the confidence that one will be able to do physical exercise due to sustained efforts, so the two scales agree on this point. We expect that an increase in a student's feeling of control will lead to that student engaging more actively not only in immediate learning tasks but in various other tasks that they will encounter in the future as well.

While "feeling of approval" depends on "friends to exercise with" in the Okazawa scale, in the present study, it reflects a feeling gained from being watched and relied on by others - in other words, "the approval of others." Here, we surmised that this has less to do with the mere presence of others in the form of teachers and friends, and more to do with the formation of confidence that comes from a fulfilled sense of acceptance when one gains the approval of others.

Furthermore, while physical competence in the Okazawa scale suggests general recognition of one's physical competence, represented by the items "I think I am outstanding" and "I may be confident," it signifies stronger confidence in this study, such as "I can do anything," which is why we named the item

Table 3 Fundamental statistics for grade and sex differences.

\begin{tabular}{|c|c|c|c|c|c|c|c|c|c|c|c|c|}
\hline & \multicolumn{4}{|c|}{ Fifth-year $(N=462)$} & \multicolumn{4}{|c|}{ Sixth-year $(N=404)$} & & & & \multirow{3}{*}{$\begin{array}{c}\text { Multiple } \\
\text { comparisons }\end{array}$} \\
\hline & \multicolumn{2}{|c|}{$\begin{array}{c}\text { Boys } \\
(N=216)\end{array}$} & \multicolumn{2}{|c|}{$\begin{array}{c}\text { Girls } \\
(N=246)\end{array}$} & \multicolumn{2}{|c|}{$\begin{array}{c}\text { Boys } \\
(N=209)\end{array}$} & \multicolumn{2}{|c|}{$\begin{array}{c}\text { Girls } \\
(N=195)\end{array}$} & \multicolumn{3}{|c|}{$F$ value } & \\
\hline & $M$ & $S D$ & $M$ & $S D$ & $M$ & $S D$ & $M$ & $S D$ & Years & Sex & Interaction & \\
\hline Feeling of control & 3.07 & .86 & 2.88 & .84 & 2.87 & .90 & 2.72 & .93 & $9.14^{* *}$ & $6.60^{* *}$ & 1.61 & $\begin{array}{c}5>6 \\
\text { Boys }>\text { Girls }\end{array}$ \\
\hline Feeling of approval & 1.93 & .79 & 1.80 & .69 & 1.94 & .74 & 1.90 & .73 & 1.19 & 2.77 & .79 & \\
\hline Feeling of omnipotence & 2.35 & .82 & 2.10 & .74 & 2.32 & .84 & 2.16 & .82 & .03 & $14.02^{* * *}$ & .67 & Boys $>$ Girls \\
\hline Feeling of superiority & 2.97 & .85 & 3.22 & .78 & 2.88 & .81 & 3.02 & .75 & 1.71 & $23.35^{* * *}$ & .08 & Girls $>$ Boys \\
\hline Feeling of progress & 2.83 & .85 & 2.45 & .82 & 2.69 & .88 & 2.37 & .80 & 3.59 & $37.74^{* * *}$ & .37 & Boys $>$ Girls \\
\hline
\end{tabular}

${ }^{* *} p<.01,{ }^{* * *} p<.001$ 
"feeling of omnipotence."

Finally, this study discovered two additional factors: "feeling of superiority" and "feeling of progress." "Feeling of superiority" is the feeling of competence that arises from comparing oneself with others, such as, "I think I am better at physical exercise than my friends" and "when I see a friend who can do exercises well, I wonder why that is." In terms of the contents, it is not simply about comparing oneself with others but is characterized by the maintenance of self-value by perceiving oneself as superior to others. As such, we used "an exaggerated notion of potential and ability" (VandenBos, 2013, p. 569), which signifies a "feeling of superiority," for this study.

A "feeling of progress" signifies the existence of clear goals and aspirations when engaging in physical education. This demonstrates that having clear or high goals is a direct means of building exercise motivation in a learner. Goals are seen as a source of motivation (Moreno et al., 2010; Moskowitz and Grant, 2009). We expect that setting goals can have a variety of effects, such as learner motivation and positive behavioral changes.

As seen above, the five factors of the physical competence scale are not only similar to those identified in past studies; we also extracted the new factors "feeling of superiority" and "feeling of progress," thus demonstrating that this scale can identify feelings of competence among the characteristics of physical education and reflects the reality of physical education. It has also been demonstrated that when it comes to the final years of elementary school, there is a stronger connection between self-evaluation and objective external standards, such as the evaluations of friends and teachers, while both self-evaluation and expectations of success in learning tasks gradually decrease through the grades and school levels (Nicholls, 1989). One reason for this is the development of the cognitive ability to understand and interpret one's evaluation of oneself. Moreover, spending time at school with friends in one's own age group increases the number of opportunities to compare oneself to others. We surmise that relative value is more evident under such conditions, strengthening self-evaluation to conform to reality.

One possible reason for the differences between our scale and the Okazawa scale might be the different scale development methods used in each case. We conducted a pilot study for this study with open-ended questions to select and carefully revise items. Consid- ering our goal to extract factors characteristic of physical education as well as the fact that we extracted "feeling of superiority," which appears to be a feeling of competence that is representative of the physical-education learning space, the scale development method in this study was effective for suggesting new insights.

\subsection{Regarding grade and sex differences}

At first, after the examination of grade differences, we found that the average score of the fifth-grade students was significantly higher than that of the sixthgrade students regarding the "feeling of control." However, the average score of the sixth-grade students was 2.80 , which is high enough to interpret that both grades demonstrated a certain degree of "feeling of control." The sixth-grade students had accumulated more experiences in physical education than the fifthgrade students had, and, therefore, the sixth-grade students may be familiar with the situation that "even if they make a great effort, it does not pay off." Sakurai (2009) reported that by the time elementary students get to the upper grades, they would have gained the ability to recognize and thus objectively evaluate their competence. Thus, the sixth graders may have scored lower than the fifth-grade students did regarding the feeling of control because they have greater experience and because they are better able to evaluate their competence objectively.

On examining sex differences, scores for "feeling of control," "feeling of omnipotence," and "feeling of progress" were found to be significantly higher in boys than in girls, while scores for "feeling of superiority," which comprised reverse items, were significantly higher in girls. The sex differences in physical competence among elementary students can be considered mainly from the following three viewpoints.

The first point is the effect of characteristic friendships among students in the upper grades of elementary school. Rose and Rudolph (2006) found that friendships between boys at upper levels of elementary school are characterized by "competition" and "ranking," while female friendships typically prioritize "prosocial behavior" such as cooperative interaction. In physical education, students have multiple opportunities to experience victory or defeat through exercise and sports. In these circumstances, boys compete with each other in a way that facilitates their development of physical competence. Meanwhile, it 
can be surmised that girls have fewer opportunities to experience physical competence as they prioritize cooperative interaction. Thus, this difference in the characteristics of friendship by sex may be a factor in sex-based differences in physical competence. It is necessary, however, to pay particular attention to boys so that their excessive obsession with competing to outrank their peers will not lead to a "feeling of superiority."

The second point to consider is the effect of an inferiority complex with regard to feelings of disgust, avoidance behavior, and passive recognition toward physical education. Sasaki and Suko (2016) revealed that girls tend to experience a greater inferiority complex in physical education at upper levels of elementary school than boys do. This suggests that girls are more likely to develop an inferior complex in physical education, which reduces their opportunities to attain successes and entertain a sense of achievement through exercise and sports. As this inferiority complex can be situated as a critical factor determining goal-oriented behavior in physical education for learners, we may guess that this leads to reduced physical competence in girls. To promote the development of such competence in girls, it is necessary to mitigate this inferiority complex toward physical education.

The third point is the effect of sex on the tendency to compare with and feel contempt for others. In this study, girls scored significantly higher on "feelings of superiority"; that is, girls were found to compare themselves with and feel contempt for others to a less extent than boys. Boys were found to have a higher tendency for comparison and contempt than girls have from an early age (Hayamizu, 2012). This general sex difference in comparison and contempt is thought to occur even in higher grades of elementary school physical education. Thus, it may be important to be aware of this danger surrounding physical competence building among boys.

Studies on self-efficacy (which is conceptually similar to competence) echo the above finding; they indicate that boys score higher in self-efficacy than girls do (Fast et al., 2010; Friedel et al., 2010; Zimmerman and Martinez-Pons, 1990). Taken together, these findings support the notion that boys are generally more likely to obtain physical competence than girls are.

\section{Conclusion}

In this study, we developed a physical competence scale for elementary school students. We used this scale to clarify the components of Japanese elementary students' physical competence in physical education and investigate grade- and sex-based differences in their physical competence. Following a pilot study, we conducted the main study on 871 elementary students using a questionnaire survey based on the scale.

An exploratory factor analysis yielded five factors of physical competence: a feeling of control, a feeling of approval, a feeling of omnipotence, a feeling of superiority, and a feeling of progress. The survey scores revealed grade- and sex-based differences: Fifth graders had significantly higher scores for a feeling of control than sixth graders did, and boys generally scored better in physical competence than girls did, except feeling of superiority.

In the present study, we sought to develop a new physical competence scale suited to the next generation of physical education students. Empirical research aimed at improving physical competence has become very popular in physical education studies in Japan, so we expect that the insights gained from this study will lead to more productive discussions in the future.

The results of this study also indicate that improving physical competence is not always positive. For instance, the "feeling of superiority" should not be encouraged. Regarding classmate interaction in physical education classes, it is essential that students overcome differences in physical strength and ability so that mutual acceptance of one another occurs. However, high levels of the "feeling of superiority" could cause serious discord in classmate interaction, including the exclusion or isolation from teams of children who are unskilled at exercise.

After that, this "feeling of superiority" can be associated with the state of the "Perspective of coexistence" (MEXT, 2018b, p. 8), which is discussed in the "Explanation of the course of study for elementary schools: Physical education edition." ${ }^{* 2}$ As this is the essence of future physical education classes, it must be monitored more closely.

In addition, physical competence must be fostered carefully by considering the effects on individual learners. For example, a greater "feeling of omnipotence" can lead to overconfidence, and a greater "feeling of progress" can create a detachment from reality, thus causing maladjustment.

Therefore, the results of this study indicate that we need to rethink the idea that teachers should always strive to improve students' physical competence lev- 
els. Instead, there is a need to explore class designs that foster physical competence appropriately while deepening an understanding of the many layers and characteristics of physical competence.

However, if learners can gain diverse experiences of what they can achieve in physical education and raise their physical competence appropriately, this will not only foster learners who independently engage in physical exercise but also form rich life experiences. To solve these issues affecting Japanese elementary school students, we must further devote ourselves to improving physical education. To this end, we hope to develop and accumulate more research in the future by investigating the following topics.

The primary focus of this study was the development of a physical competence scale based on problems identified in previous studies on physical competence, but future studies should propose a factor model for physical competence, for example by examining connections with actual learning results or combinations of factors such as classroom atmosphere and its effect on students' physical competence level.

\section{Acknowledgment}

We would like to sincerely thank the teachers and students for so graciously taking the time to complete the questionnaires that are the important data for this study.

\section{Notes}

*1 Competence is conceptually similar to self-efficacy. Selfefficacy was defined by Bandura (1977) as a belief in one's ability to perform an action necessary to accomplish a task. The stronger a person's self-efficacy is, the more likely they are to accomplish the task. In other words, self-efficacy describes a person's level of confidence in their ability to accomplish something. As such, the concept concerns a person's ability just as the concept of competence does. However, the two concepts are not entirely identical; whereas selfefficacy predicts behavior, competence is a product of behavior. Accordingly, we have treated competence and self-efficacy as separate concepts.

*2 The "Explanation of the course of study for elementary schools: Physical education edition" stipulates that the aim of physical education is "to enhance educational content so that students can share diverse ways of entertaining exercise and sports, regardless of their physical strength, skills, age, sex, and presence of disabilities, with an emphasis on various ways of relating to exercise and sports" (MEXT, 2018b, p. 8). Based on this, physical education aims "to place importance on the perspective of coexistence and improve it" (MEXT, 2018b, p. 8). In other words, future physical education requires collaboration with peers while paying respect to diversity, and in so doing, realizing an inclusive society through exercise and sports. However, since an elevated "feeling of superiority" may impair the relationship among peers, it is important to closely observe the development of a "feeling of superiority" in the interest of fostering coexistence.

\section{References}

Bandura, A. (1977). Self-efficacy: Toward a unifying theory of behavioral change. Psychol. Rev., 84: 191-215.

Deci, E. L. and Ryan, R. M. (1985). Intrinsic motivation and self-determination in human behavior. New York: Plenum Press.

Deci, E. L. and Ryan, R. M. (2002). Handbook of self-determination research. New York: The University of Rochester Press.

Fast, L. A., Lewis, J. L., Bryant, M. J., Bocian, K. A., Cardullo, R. A., Rettig, M., and Hammond, K. A. (2010). Does math selfefficacy mediate the effect of the perceived classroom environment on standardized math test performance? J. Educ. Psychol., 102: 729-740.

Ferrer, C. E. and Weiss, M. R. (2000). Predictors of intrinsic motivation among adolescent students in physical education. Res. Q. Exerc. Sport., 71(3): 267-279.

Friedel, J. M., Cortina, K. S., Turner, J. C., and Midgley, C. (2010). Changes in efficacy beliefs in mathematics across the transition to middle school: Examining the effects of perceived teacher and parent goal emphases. J. Educ. Psychol., 102: 139158.

Harter, S. (1978). Effectance motivation reconsidered: Toward a development model. Hum. Dev., 21: 34-64.

Harter, S. (1981). A new self-reported scale of intrinsic versus extrinsic orientation in the classroom: Motivational and informational components. Dev. Psychol., 17: 300-312.

Harter, S. (1982). The perceived competence scale for children. Child Dev., 53: 87-97.

Harter, S. and Pike, R. (1984). The pictorial scale of perceived competence and social acceptance for young children. Child Dev., 55(6): 1969-1982.

Harter, S. and Zigler, E. (1974). The assessment of effectance motivation in normal and retarded children. Dev. Psychol., 10: 169-180.

Hassandra, M., Goudas, M., and Chroni, S. (2003). Examining factors associated with intrinsic motivation in physical education: A qualitative approach. Psychol. Sport Exerc., 4(3): 211223.

Hayamizu, T. (2012). Psychology of assumed competence based on undervaluing others. Kyoto: Kitaoji Shobo. (in Japanese).

Hayamizu, T., Kino, K., Takagi, K., and Tan, E. H. (2004). Assumed-competence based on undervaluing others as a determinant of emotions: Focusing on anger and sadness. Asia Pac. Educ. Rev., 5: 127-135.

Ito, T. (1987). Effects of attributional style and perceived physical competence on sport behavior: An examination of causal attribution model about sport behavior of university students. J. Phys. Educ. Health Sport Sci., 31(4): 263-271. (in Japanese).

Kage, M. (2013). Gakushu iyoku no riron: Dokiduke no kyoiku shinrigaku [Theory of the motivation for learning: Educational psychology of motivation]. Tokyo: Kaneko Shobo. (in Japanese).

Ministry of Education, Culture, Sports, Science and Technology. (2018a). Shogakko gakushu shido yoryo [Course of study for elementary schools]. Tokyo: Toyokan Shuppansha. (in Japanese).

Ministry of Education, Culture, Sports, Science and Technology. (2018b). Shogakko gakushu shido yoryo kaisetsu taiiku hen [Explanation of the course of study for elementary schools: Physical education edition]. Tokyo: Toyokan Shuppansha. (in Japanese).

Moreno, J. A., Conte, L., Gonzalez Cutre, D., Martin Albo, J., and Nunez, J. L. (2010). Effects of a task climate intervention on students' motivation in sport instruction. Estud. Psicol-Madrid, 
31(1): 67-77.

Moskowitz, G. B. and Grant, H. (2009). The psychology of goals. New York: Guilford Press.

Nicholls, J. G. (1989). The competitive ethos and democratic education. Cambridge, MA: Harvard University Press.

Okazawa, Y., Kita, M., and Suwa, Y. (1996). Factorial structure of physical competence and its developmental tendency and sex difference. Jpn. J. Sport. Edu. Studies., 16: 145-155. (in Japanese).

Rose, A. J. and Rudolph, K. D. (2006). A review of sex differences in peer relationship processes: Potential trade-offs for the emotional and behavioral development of girls and boys. Psychol. Bull., 132(1): 98-131.

Rosenberg, M. (1965). Society and the adolescent self-image. Princeton: Princeton University Press.

Sakurai, S. (1983). Development of the Japanese edition of the Harter's Perceived Competence Scale for Children. Jpn. J. Educ. Psychol., 31(3): 245-249. (in Japanese).

Sakurai, S. (1992). The investigation of Self-Consciousness in the 5th- and 6th-grade children. Jpn. J. Exe. Socio. Psychol., 31(1): 85-94. (in Japanese).

Sakurai, S. (2009). Psychology of voluntary motive for learning. Tokyo: Yuhikaku. (in Japanese).

Sasaki, B. and Suko, R. (2016). The factorial concept of inferiority complexes and their relationship with students' personal characteristics regarding physical education. J. Phys. Educ. Health Sport Sci., 61(2): 663-680. (in Japanese).

Sugihara, T. (2003). Psychology of motor learning and motivation. Tokyo: Taishukan Publishing. (in Japanese).

Susaki, Y. and Anii, A. (2013). The examination of validity, reliability and factor structure of Self-Esteem Scale by Rosenberg for elementary and junior high school students. J. Life. Needs Exp. Learn., 13: 93-98. (in Japanese).

VandenBos, G. R. (2013). APA dictionary of clinical psychology. Washington, DC: American Psychology Association.

White, R. W. (1959). Motivation reconsidered: the concept of competence. Psychol. Rev., 66: 297-333.

White, R. W. (1963). Ego and reality in psychoanalytic theory. New York: International Universities Press.

Zeigler-Hill, V. (2013). The importance of self-esteem. In V. Zeigler-Hill (Ed.), Self-esteem (pp. 1-20). New York, NY: Psychology Press.

Zimmerman, B. J. and Martinez-Pons, M. (1990). Student differences in self-regulated learning: Relating grade, sex, and giftedness to self-efficacy and strategy use. J. Educ. Psychol., 82: 51-59.

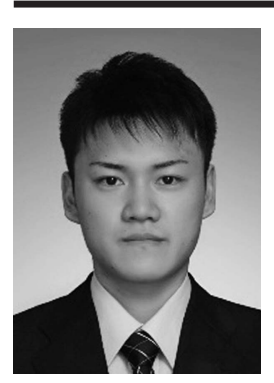

Name:

Yuta Ono

\section{Affiliation:}

Faculty of Sport Sciences, Waseda University

\section{Address:}

3-4-1, Higashifushimi, Nishitokyo, Tokyo, 202-0021, Japan

Brief Biographical History:

Apr 2016-Mar 2018 Research Associate of Faculty of Sport Sciences, Waseda University

Apr 2018-Mar 2019 Assistant Professor of Faculty of Sports Sciences, Waseda University

Apr 2019-Lecturer of Faculty of Sports Sciences, Waseda University

\section{Main Works:}

- Ono, Y. and Kaji, M. (2020). Study on the concept of learning by elementary school students in physical education classes in Japan. Journal of Physical Education and Sport, In Press.

-Ono, Y., Kaji, M., Tozmozoe, H., and Yoshinaga, T. (2019). Who is the student athlete? Focusing on positioning in the campus unrest period in Japan. Sport in Society, In Press.

• Ono, Y., Tomozoe, H., Takahashi, S., Fukami, E., Yoshinaga, T., and Nemoto, S. (2018). Conceptions of learning and learning strategies of students in junior high school physical education. Jpn. J. Phys. Educ. Health Sport Sci., 63: 215-236. (in Japanese).

-Ono, Y., Tomozoe, H., and Nemoto, S. (2017). A study on the Formation Process of Sports Recommendation Admissions to Universities in Japan. Jpn. J. Phys. Educ. Health Sport Sci., 62: 599-620. (in Japanese).

\section{Membership in Learned Societies:}

- Japan Society of Physical Education, Health and Sport Sciences

-Japan Society for the Pedagogy of Physical Education

- Japanese Society of Sport Education

- Japan Society of Sport Sociology

- Japanese Association of Educational Psychology

-Japan Society of Educational Sociology 